\title{
Presenilin-1-Dependent Transcriptome Changes
}

\author{
Károly Mirnics, ${ }^{1,2 *}$ Zeljka Korade, ${ }^{3 *}$ Dominique Arion, ${ }^{1}$ Orly Lazarov, ${ }^{4}$ Travis Unger, ${ }^{1}$ Melissa Macioce, ${ }^{1}$ \\ Michael Sabatini, ${ }^{1,2}$ David Terrano, ${ }^{4}$ Katherine C. Douglass, ${ }^{1}$ Nina F. Schor, ${ }^{3}$ and Sangram S. Sisodia ${ }^{4}$ \\ Departments of ${ }^{1}$ Psychiatry, ${ }^{2}$ Neurobiology, and ${ }^{3}$ Pediatrics, University of Pittsburgh School of Medicine, Pittsburgh, Pennsylvania 15261 , and ${ }^{4}$ Center for \\ Molecular Neurobiology, University of Chicago, Chicago, Illinois 60637
}

Familial forms of Alzheimer's disease (FADs) are caused by the expression of mutant presenilin 1 (PS1) or presenilin 2. Using DNA microarrays, we explored the brain transcription profiles of mice with conditional knock-out of PS1 (cKO PS1) in the forebrain. In parallel, we performed a transcription profiling of the hippocampus and frontal cortex of the FAD-linked $\Delta \mathrm{E} 9$ mutant transgenic (TG) mice and matched controls [TG mice expressing wild-type human PS1 (hPS1)]. When the TG and cK0 datasets were cross-compared, the majority of the 30 common expression alterations were in opposite direction, suggesting that the FAD-linked PS1 variant produces transcriptome changes primarily by gain of aberrant function. Our microarray studies also revealed an unanticipated inverse correlation of transcript levels between the brains of mice that coexpress $\Delta \mathrm{E} 9 h P S 1+$ amyloid precursor protein $(\mathrm{APP})_{695}$ Swe and $\Delta \mathrm{E} 9 \mathrm{hPS} 1$ single transgenic mice. The opposite directionality of these changes in transcript levels must be a function of APP and/or APP derivatives.

Key words: presenilin; DNA microarray; Alzheimer's disease; gene expression; transcriptome; animal model

\section{Introduction}

Presenilins are highly homologous membrane proteins that play an essential role in processing of amyloid precursor protein (APP), leading to the production of $\beta$-amyloid $(\mathrm{A} \beta)$ peptides (for review, see Price et al., 1998; Selkoe, 2001; De Strooper, 2003; Van Gassen and Annaert, 2003). Mutations in mutant presenilin 1 (PS1) and presenilin 2 (PS2) lead to familial forms of Alzheimer's disease (FAD) (Rogaev et al., 1995; Sherrington et al., 1995) and are characterized by enhanced production of $\mathrm{A} \beta_{42}$ peptides (Borchelt et al., 1996; Duff et al., 1996; Scheuner et al., 1996; Borchelt et al., 1997). However, the cellular response(s) to FADlinked PS1 variants are not fully understood and involves simultaneous "gain of function" and "loss of function" properties (Cai et al., 2003; Marjaux et al., 2004; Saura et al., 2004).

Over the last several years, we have seen a revolution in highthroughput expression profiling of diseased human brain tissue (Ginsberg et al., 2000; Ho et al., 2001; Loring et al., 2001; Colangelo et al., 2002; Mufson et al., 2002; Yao et al., 2003; Blalock et al., 2004) and various models of human brain disorders (Dickey et al., 2003, 2004; Marcotte et al., 2003; Mirnics et al., 2003; Gan et al., 2004; Wang et al., 2004). Although the expression profiling of $\mathrm{AD}$ tissue continues to generate data of enormous potential, the

Received Oct. 6, 2004; revised Dec. 10, 2004; accepted Dec. 11, 2004.

This work was supported by a National Alliance for Research on Schizophrenia and Depression Young Investigator Award (K.M.), a National Institutes of Health (NIH) Training Grant and the Pittsburgh Institute for Neurodegenerative Diseases (Z.K.), a Craumer Endowment of Children's Hospital of Pittsburgh (N.F.S.), NIH Grant AG021494 (S.S.S., 0.L., D.T.), and the Ellison Medical Foundation (S.S.S., O.L., D.T.). We thank Dr. Pat R. Levitt for valuable comments on this manuscript. We also thank Carmel F. Portugal for superb technical assistance with the experiments.

*K.M. and Z.K. contributed equally to this work.

Correspondence should be addressed to either of the following: Károly Mirnics, Department of Psychiatry, University of Pittsburgh, School of Medicine, E1453 Biomedical Science, Pittsburgh, PA 15261, E-mail: karoly+@pitt.edu; or Sangram S. Sisodia, Center for Molecular Neurobiology, The University of Chicago, 947 East 58th Street, MC 0926, Chicago, IL 60637, E-mail: ssisodia@drugs.bsd.uchicago.edu.

DOI:10.1523/JNEUROSCI.4145-04.2005

Copyright $\odot 2005$ Society for Neuroscience $\quad$ 0270-6474/05/251571-08\$15.00/0 interpretation of the postmortem findings is greatly complicated by the nature of AD disease progress (Mirnics et al., 2001a; Marcotte et al., 2003; Mirnics and Pevsner, 2004).

In an attempt to identify genes for which transcription depends on normal PS1 function, we first performed a transcriptome profiling of the frontal cortex (FC) and hippocampus of mice with a conditional ablation of the PS1 gene. Once we defined the gene expression pattern of the PS1-deficient mice, the $\triangle \mathrm{E} 9$ mutant human PS1 (hPS1) transgenic animal model attracted our attention (Lee et al., 1997; Lazarov et al., 2002). Inheritance of a single allele of $P S 1$ with a deletion of exon 9 results in early onset FAD in several independent pedigrees. However, because the endogenous APP production in the mouse brain is low, these mice do not develop amyloid deposits or other pathology associated with $\mathrm{AD}$, and as such, may mimic the premorbid phase of human $\mathrm{AD}$. As a result, data obtained in brain transcriptome profiling of $\triangle$ E9 hPS1 mice would allow the assessment of the molecular consequences of the mutation but without the interference from cell loss or secondary transcriptome changes resulting from amyloid deposition or associated neuropathological features.

We focused our attention on the following questions in the current study. First, what are the gene expression consequences of PS1 ablation? Second, what are the transcriptome changes that arise from expression of human $\triangle \mathrm{E} 9$ PS1 in mice? Third, are the genes for which expression level is modulated by conditional ablation of PS1 also regulated in mice carrying the $\triangle \mathrm{E} 9 \mathrm{hPS} 1$ mutation? Finally, how do the transcriptome responses caused by expression of $\triangle \mathrm{E} 9$ hPS1 alone relate to those in which this polypeptide is coexpressed with the FAD-linked $\mathrm{APP}_{695}$ Swedish variant?

\section{Materials and Methods}

Experimental animals

Because we were interested in early transcriptome events, all transgenic animals used in the current study were killed at 3 months of age. All 
Table 1. Common TG- cKO changes
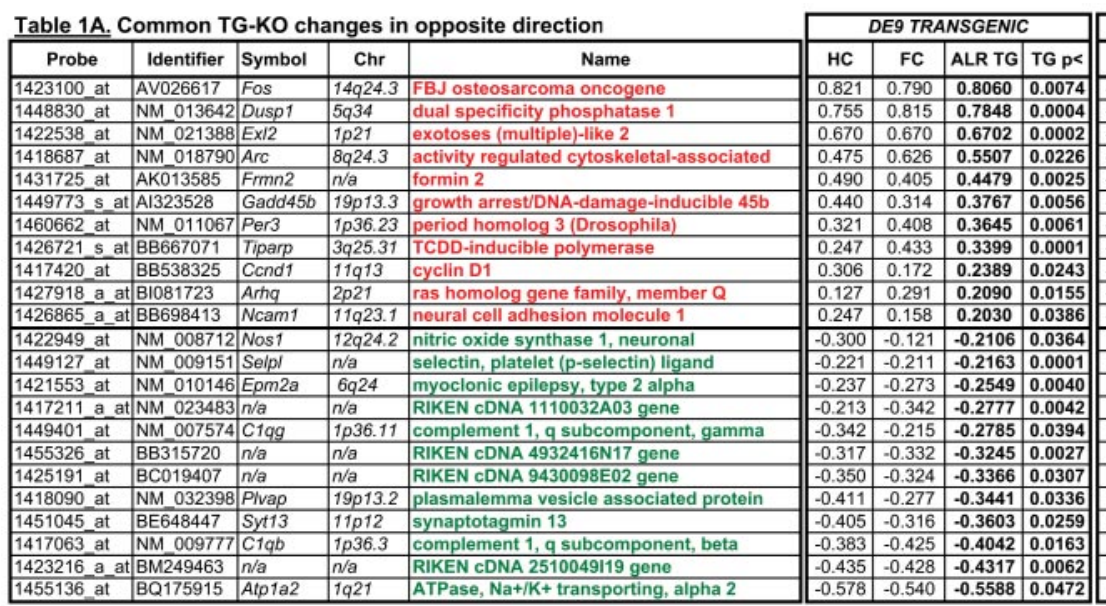

\begin{tabular}{|c|c|c|c|}
\hline \multicolumn{4}{|c|}{ CONDITIONAL KNOCKOUT } \\
\hline HC & FC & ALR KO & KO p \\
\hline 0.823 & -0.786 & -0.8047 & 0.0000 \\
\hline-0.360 & -0.349 & -0.3545 & 0.0256 \\
\hline 0.304 & 400 & & \\
\hline-0.746 & -0.578 & -0.6620 & 0.0005 \\
\hline-0.311 & -0.335 & & 0.0261 \\
\hline-0.229 & -0.238 & -0.2332 & \begin{tabular}{|l}
0.0247 \\
\end{tabular} \\
\hline-0.448 & -0.352 & 99 & 0.0150 \\
\hline-0.256 & -0.374 & & 0.0 \\
\hline-0.250 & -0.165 & 78 & 0.0138 \\
\hline-0.107 & -0.397 & 20 & 0.0262 \\
\hline-0.197 & -0.305 & -0.2511 & 0.0412 \\
\hline 0.170 & 0.254 & & 0.0139 \\
\hline 0.083 & 360 & 0.2218 & 0.0009 \\
\hline 0.484 & & & 0.0029 \\
\hline 0.227 & 352 & 94 & 0.0135 \\
\hline 0.162 & 0.541 & 0.3514 & 0.0006 \\
\hline 0.090 & 341 & 02158 & 00454 \\
\hline 0.202 & 414 & 0.3078 & 0.0002 \\
\hline 0.379 & 355 & 0.3672 & 0.0004 \\
\hline 0.358 & 0.425 & 0.3914 & 0.0044 \\
\hline 0.318 & 0.708 & 0.5129 & 0.0001 \\
\hline 0.299 & 0.18 & 0.2422 & \\
\hline 0.338 & 0.323 & 0.3305 & 0.0496 \\
\hline
\end{tabular}

\begin{tabular}{|c|c|c|}
\hline \multicolumn{3}{|c|}{ COMPARISON } \\
\hline HC: TG-Ko & FC: TG-Ko & Overall p< \\
\hline Up-Down & Up-Down & 0.00001 \\
\hline Up-Down & Up-Down & 0.00012 \\
\hline Up-Down & Up-Down & 0.00006 \\
\hline Up-Down & Up-Down & 0.00015 \\
\hline Up-Down & Up-Down & 0.00069 \\
\hline Up-Down & Up-Down & 0.00136 \\
\hline Up-Down & Up-Down & 0.00094 \\
\hline Up-Down & Up-Down & 0.00001 \\
\hline Up-Down & Up-Down & 0.00302 \\
\hline Up-Down & Up-Down & 0.00359 \\
\hline Up-Down & Up-Down & 0.01185 \\
\hline Down-Up & Down-Up & 0.00434 \\
\hline Down-Up & Down-Up & 0.00000 \\
\hline Down-Up & Down-Up & 0.00014 \\
\hline Down-Up & Down-Up & 0.00061 \\
\hline Down-Up & Down-Up & 0.00028 \\
\hline Down-Up & Down-Up & 0.00123 \\
\hline Down-Up & Down-Up & 0.00008 \\
\hline Down-Up & Down-Up & 0.00016 \\
\hline Down-Up & Down-Up & 0.00115 \\
\hline Down-Up & Down-Up & 0.00002 \\
\hline Down-Up & Down-Up & 0.00081 \\
\hline Down-Up & Down-Up & 0.01636 \\
\hline
\end{tabular}

Table 1B. Common TG-KO changes in same direction
\begin{tabular}{|c|l|l|l|l||}
\hline Probe & Identifier & Symbol & \multicolumn{1}{c|}{ Chr } & \multicolumn{1}{c|}{ Name } \\
\hline 1452705 at & AK004611 & $n / a$ & $n / a$ & Pyridoxal-dep. decarboxylase family \\
\hline 1451447 at & BC024476 & $n / a$ & $n / a$ & RIKEN cDNA C 330016016 gene \\
\hline 1415694 at & AK004541 & Wars & $14 q 32.31$ & tryptophanyl-tRNA synthetase \\
\hline 1419665 a_at & NM 019738 & Nupr 1 & $16 p 11.2$ & nuclear protein 1 (p8 protein) \\
\hline 1450154 at & NM 016770 & Folh1 1 & $11 p 11.2$ & folate hydrolase \\
\hline 1436547 at & AV274554 & Dgke & $17 q 22$ & diacylglycerol kinase, epsilon \\
\hline 1439241 x_at & BB825787 & n/a & $n / a$ & steroid 5 alpha-reductase 2-llike \\
\hline
\end{tabular}

\begin{tabular}{|c|c|c|c||}
\hline \multicolumn{4}{|c|}{ DE9 TRANSGENIC } \\
\hline HC & FC & ALR TG & TG $\mathbf{p <}$ \\
\hline 1.365 & 1.106 & $\mathbf{1 . 2 3 5 6}$ & $\mathbf{0 . 0 0 3 0}$ \\
\hline 0.672 & 0.469 & $\mathbf{0 . 5 7 0 4}$ & $\mathbf{0 . 0 0 3 7}$ \\
\hline 0.550 & 0.559 & $\mathbf{0 . 5 5 4 4}$ & $\mathbf{0 . 0 0 7 0}$ \\
\hline 0.404 & 0.238 & $\mathbf{0 . 3 2 1 4}$ & $\mathbf{0 . 0 0 0 6}$ \\
\hline-0.325 & -0.109 & $-\mathbf{0 . 2 1 7 2}$ & $\mathbf{0 . 0 3 1 1}$ \\
\hline-0.361 & -0.138 & $-\mathbf{- 0 . 2 4 9 3}$ & $\mathbf{0 . 0 3 6 5}$ \\
\hline-0.398 & -0.496 & $\mathbf{- 0 . 4 4 7 0}$ & $\mathbf{0 . 0 0 0 6}$ \\
\hline
\end{tabular}

\begin{tabular}{|c|c|c|c||}
\hline \multicolumn{4}{|c|}{ CONDITIONAL KNOCKOUT } \\
\hline HC & FC & ALR KO & KO $\mathbf{p}<$ \\
\hline 0.311 & 0.481 & $\mathbf{0 . 3 9 5 8}$ & $\mathbf{0 . 0 4 6 5}$ \\
\hline 0.228 & 0.287 & $\mathbf{0 . 2 5 7 5}$ & $\mathbf{0 . 0 0 5 7}$ \\
\hline 0.253 & 0.379 & $\mathbf{0 . 3 1 6 0}$ & $\mathbf{0 . 0 4 8 5}$ \\
\hline 0.321 & 0.163 & $\mathbf{0 . 2 4 1 7}$ & $\mathbf{0 . 0 0 8 2}$ \\
\hline-0.290 & -0.286 & $\mathbf{- 0 . 2 8 7 8}$ & $\mathbf{0 . 0 1 4 1}$ \\
\hline-0.233 & -0.247 & $\mathbf{- 0 . 2 4 0 1}$ & $\mathbf{0 . 0 0 6 3}$ \\
\hline-0.180 & -0.244 & $\mathbf{- 0 . 2 1 2 0}$ & $\mathbf{0 . 0 1 7 2}$ \\
\hline
\end{tabular}

\begin{tabular}{|c|c|c|}
\hline \multicolumn{3}{|c|}{ COMPARISON } \\
\hline HC: TG-Ko & FC: TG-Ko & Overall p< \\
\hline Up-Up & Up-Up & 0.00138 \\
\hline Up-Up & Up-Up & 0.00025 \\
\hline Up-Up & Up-Up & 0.00307 \\
\hline Up-Up & Up-Up & 0.00006 \\
\hline Down-Down & Down-Down & 0.00381 \\
\hline Down-Down & Down-Down & 0.00216 \\
\hline Down-Down & Down-Down & 0.00014 \\
\hline
\end{tabular}

Probe, Affymetrix probeset; Identifier, National Center for Biotechnology Information accession number; Chr, chromosomal position of gene sequence; $p<$, Student's t test probability; Overall $p<$, overall $p$ value calculated by $\chi$ distribution.

animals used in this study have been described previously. Briefly, $\Delta \mathrm{E} 9$ hPS1 mice and mice carrying the human wild-type (wt) PS1 express similar levels of PS1 transcripts, and the encoded proteins accumulate to levels observed in nontransgenic mice (Borchelt et al., 1997; Lee et al., 1997; Lazarov et al., 2002) but result in enhanced production of $\mathrm{A} \beta_{42}$ peptides. Both cDNAs are driven by the mouse prion protein promoter and are expressed in a ubiquitous manner across the mouse brain. However, both the human wild-type and mutant PS1 polypeptides fully replace the mouse $P S 1$ polypeptides by competing for limiting stabilization factors (Thinakaran et al., 1996; Lee et al., 1997). The $\triangle \mathrm{E} 9$ hPS1 mice show increased production of $\mathrm{A} \beta_{42}$ peptides but do not develop FAD microscopic pathology.

Mice coexpressing FAD mutant human PS1- $\triangle \mathrm{E} 9$ and a chimeric mouse-human $\mathrm{APP}_{695}$ harboring a human $\mathrm{A} \beta$ domain and mutations (K595N, M596L) linked to Swedish FAD pedigrees ( APP $_{\text {swe }}$ ) have been described previously (Borchelt et al., 1997). Hippocampi of eight mice were analyzed on the same microarray platform as part of an independent environmental enrichment study. We established previously that the expression of the mutant PS1 transgene-encoded polypeptide, $\Delta \mathrm{E} 9$, in the APP-overexpressing mice is identical to the levels seen in mice that express PS1 $\triangle \mathrm{E} 9$ alone (data not shown).

Conditional PS1 ablation in the forebrain is achieved via cre-lox recombination under calmodulin kinase 2 control (Feng et al., 2001). We have shown previously by in situ hybridization that PS1 mRNA expression is no longer present in the forebrain of 10-month-old animals, and we subsequently established that forebrain ablation of PS1 expression occurs at 6 months of age. Furthermore, in a parallel study of conditional knock-out (cKO) WT mouse PS1 (mPS1), using the same CamK11cre transgene to conditionally ablate $P S 1$, Yu et al. (2001) demonstrated that $P S 1$ protein expression is reduced by $>90-95 \%$ at 6 months of age. The remaining levels of PS1 most likely represent PS1 expression in glial cells and vascular-associated cell types and is expected, because the conditional ablation occurs in a neuron-specific manner. Furthermore, the same study reported that PS2 expression is not altered as a consequence of ablating PS1 expression, whereas the levels of $\mathrm{A} \beta_{40}$ and $\mathrm{A} \beta_{42}$ were reduced by $\sim 73$ and $\sim 25 \%$, respectively. Unlike PS1/PS2-deficient mice (Saura et al., 2004), our mice with a conditional ablation of PS1 are viable and do not show alterations in postenrichment contextual memory.

\section{Sample preparation and hybridization}

Hippocampi and frontal cortices were rapidly dissected, frozen on dry ice, and stored at $-80^{\circ} \mathrm{C}$ until RNA isolation. Total RNA was isolated using the Trizol reagent. RNA quality was assessed using the Agilent Technologies (Palo Alto, CA) Bioanalyzer. Reverse transcription (RT), in vitro transcription, and fragmentation were performed according to the recommendation of the manufacturer. Samples were hybridized onto MOE430A mouse Affymetrix (Santa Clara, CA) GeneChips, which contained $>22,000$ probe sets, using the Affymetrix hybridization station. To avoid microarray batch variation, only microarrays from a single lot were used. Microarrays were considered for use only if the average $3^{\prime}: 5^{\prime}$ ratio for glyceraldehyde-3-phosphate dehydrogenase (GAPDH) and actin did not exceed 1:1.2. Of the 40 samples, three failed to meet these criteria. These were excluded from additional analyses and are denoted by the gray outline in the experimental design (see Fig. 1). Segmentation of scanned microarray images was performed by Microarray Analysis Suite 5.0. (Affymetrix). Determination of expression levels and scaling were performed using robust multichip average (Irizarry et al., 2003a,b).

\section{Data analysis}

Identification of differentially expressed genes. We identified genes as differentially expressed in the wt $h P S 1-\triangle \mathrm{E} 9 h P S 1$ and wt $m P S 1$-cKO mPS1 comparisons if they, first, reported $>0.2$ average log ratio in both the hippocampal cortex (HC) and FC comparisons and, second, if the $p$ value for both the $\mathrm{FC}$ and $\mathrm{HC}$ comparisons was $<0.05$. These combined criteria further increased the reliability of the data by elimination of significant, but very small, expression changes that may have a marginal biological effect (Mirnics and Pevsner, 2004).

Calculation of pooled significance. Because the expression levels are different between brain regions, the outcomes of the comparisons have to be compared independently. For calculating the combined significance between the transgenic (TG) and cKO comparisons (Table 1), the $\chi$ distribution was calculated as follows: $-2^{*}[\ln (p$ value for TG comparison $)+\ln (p$ value for $\mathrm{CKO}$ comparison $)]$. The calculation was performed with four degrees of freedom.

Correlations. Correlations were calculated using Pearson's $r$ value for the $\log _{2}$ ratios between the two compared conditions.

False discovery ratio estimate. False discovery ratio (FDR) was assessed in a permutation test, in which equal numbers of experimental and con- 


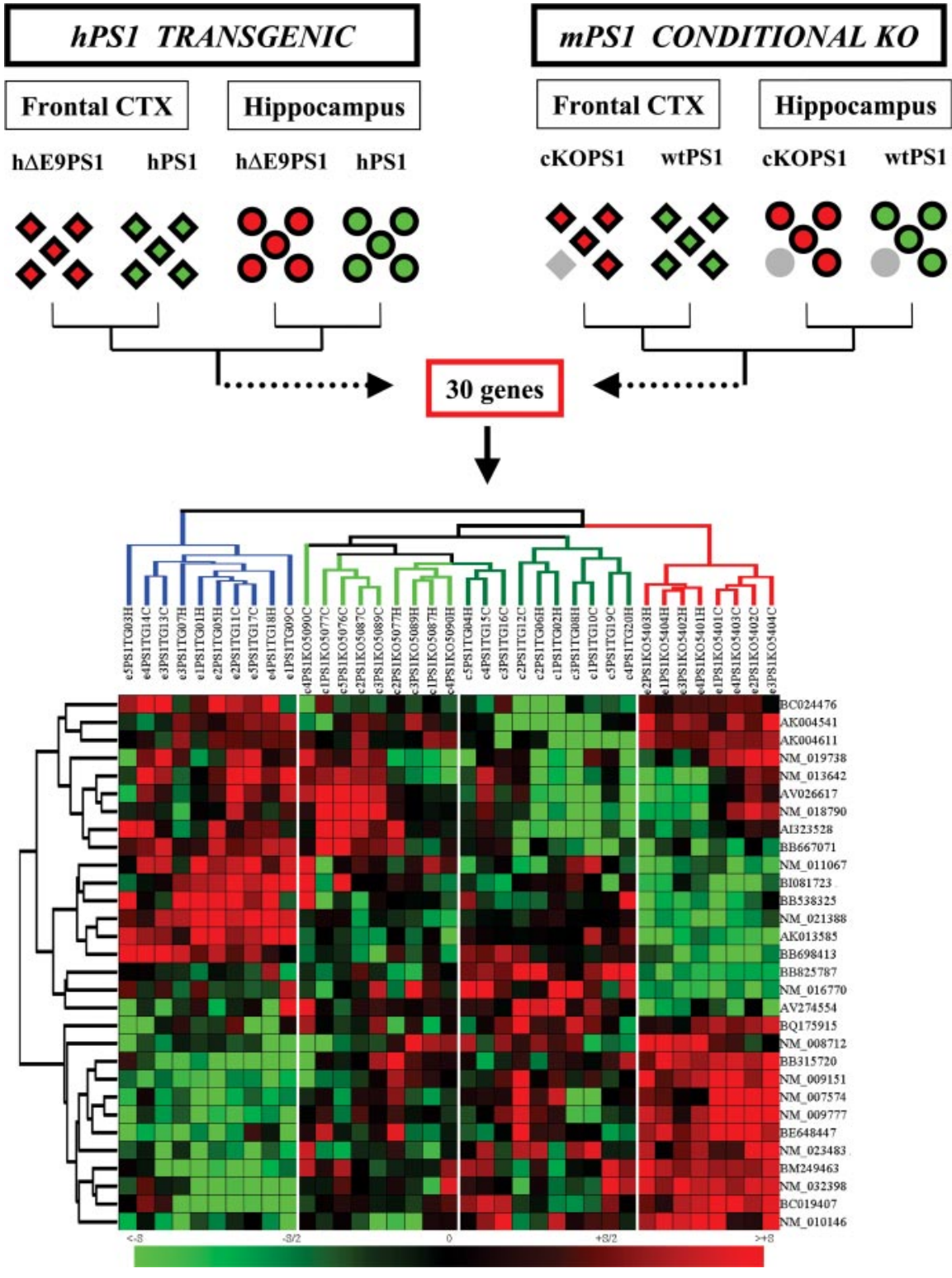

Figure 1. Experimental summary. Top, The experimental series was performed using $40 \mathrm{MOE} 430 \mathrm{~A}$ GeneChip oligonucleotide arrays with $>22,000$ gene probe sets. $\triangle$ E9 hPS1 transgenic animals were compared with mice carrying the human wild-type PS1 gene, and conditional knock-out mice were compared with mice that did not undergo cre-lox recombination. The analysis was performed on hippocampus and frontal cortex tissue. Thirty genes were identified as differentially expressed across the HC and FC of both $\triangle \mathrm{E} 9$ hPS1-wt $h P S 1$ and CKO mPS1-wt mPS1 comparisons. Bottom, Two-way clustering of the normalized expression levels for these 30 genes separated the mouse genotypes according to their expression phenotype. In the vertical dendrogram, each arm represents a single animal (red, CK0; blue, $\triangle \mathrm{E} 9$ hPS1; light green, wild-type mouse PS1; dark green, wild-type hPS1), and rows denote gene probe sets with National (enter for Biotechnology Information accession numbers. Note that the CKO mice and $\triangle \mathrm{E} 9$ mice show the largest Euclidian distance, whereas the wt $\mathrm{MPS} 1$ and wt $h P S 1$ animals cluster adjacently. For gene names and statistical parameters, see Table 1.

trol microarrays were randomly assigned to two groups (supplemental material 1, available at www.jneurosci.org). These groups were assessed for gene expression differences with the same analysis as in the experimental-control comparison. FDR was established for each of the five permutations performed, and the mean FDR was calculated by averaging the FDR obtained in each of the permutation tests.

Clustering. Two-way clustering (sample and gene vectors) was performed on RMA-generated $\log _{2}$-transformed expression levels using Euclidian distance measurement in Genes@Work developed by IBM (IBM Corporation, White Plains, NY) (Lepre et al., 2004).

Custom database. RMA normalized data and statistical measurements were imported into Microsoft Access (Microsoft, Seattle, WA). This da- tabase is searchable by significance, accession number, log ratio, and gene name. The database displays individual RMA normalized data points across all experimental conditions.

Data sharing. The Microsoft Access database with all data points $(\sim 130 \mathrm{MB})$ is available on request. All of the raw microarray data have been deposited into a Gene Expression Omnibus (Edgar et al., 2002; Wheeler et al., 2004) in a Minimum Information about a Microarray Experiment/Microarray Gene Expression Data Society (Brazma et al., 2001; Ball et al., 2002; Causton and Game, 2003) compliant format and are publicly available without any restrictions.

\section{In situ hybridization}

In situ hybridization was performed by methods described previously (Mirnics et al., 2001b). Briefly, after designing gene-specific primers, 600-900 bp amplicons were obtained in a standard PCR. The resulting products were cloned into a vector by T/A cloning. All clones were verified by sequencing. ${ }^{35} \mathrm{~S}$-labeled antisense riboprobes were generated using T7-SP6 in vitro transcription and were cleaned and hybridized overnight to the tissue sections $(2,000,000 \mathrm{dpm} /$ slide $)$. After washing, slides were exposed to $\mathrm{x}$-ray film for up to $3 \mathrm{~d}$ and subsequently dipped in photoemulsion. Dipped slides were developed after 3-14 d, depending on the strength of the radioactive signal observed in film exposures. In all experiments, sense riboprobe was used as a specificity control.

\section{Real-time quantitative PCR}

For selected genes, quantitative PCR (qPCR) was performed on pooled samples from the five groups of animals (wt hPS1, $\triangle \mathrm{E} 9 \mathrm{hPS1}$, wt $m P S 1$, cKO mPS1, and $\left.\triangle \mathrm{E} 9 h P S 1 \times \mathrm{APP}_{695}\right)$. After primer validation for amplification efficiency (95-100\%), the experiment was performed using standard $\Delta$ Ct-Sybr Green measurement protocols with two independent reverse transcriptions and four replicates per RT (Mimmack et al., 2004). GAPDH was used as a standard normalizer. Primer sequences are available in supplemental material 2 (available at www.jneurosci.org).

\section{Results}

RNA was harvested from HCs and FCs from five CKO mPS1 and five control wt mPS1 animals. Conditional ablation is achieved by cre-lox recombination under calmodulin kinase 2 control previously generated in our laboratory (Fig. 1, top right). These $\mathrm{cKO}$ mice are viable and do not develop any obvious pathology with aging. Each sample was hybridized to a single MOE430AGeneChip (20 arrays in total). The obtained intensity measurements were normalized by RMA (Irizarry et al., 2003a,b) and imported into a custom-made Microsoft Access database. Because we were interested in the overall influence of the PS1 ablation on the transcriptome of two $\mathrm{AD}$-affected brain regions, we focused our attention to expression changes that were present in both $\mathrm{HC}$ and FC. This analysis identified 85 genes that were differentially expressed 
across both regions (Fig. 1) (supplemental material 3, available at www.jneurosci.org) and will be referred to as the "KO comparison." For these 85 genes, the correlation between the outcome of the HC and FC comparisons was $r=0.96(p<0.0001)$. The number of genes with increased and decreased expression was evenly distributed, with transcript reductions showing a greater magnitude than transcript inductions.

Once we defined a PS1-dependent transcript network, we were interested to determine whether the expression profiles of the cKO animal share any commonalities with that of humanized mice carrying the $\triangle \mathrm{E} 9 \mathrm{hPS} 1$ mutation. As a result, we chose to perform a microarray analysis on the $\mathrm{HC}$ and $\mathrm{FC}$ of the $\triangle \mathrm{E} 9 \mathrm{hPS} 1$ mutants using a similar experimental design used in the $\mathrm{CKO}$ experiment. We hypothesized that the most critical expression changes produced the conditional ablation of PS1 might also appear in the $\triangle \mathrm{E} 9 \mathrm{hPS} 1$ variant. We speculated that if the mutant human PS1 polypeptide was a hypermorph, or "gain of function" species, differences in $\triangle \mathrm{E} 9$ hPS1 mice would be in the opposite direction than in the PS1 cKO animals. However, if both the $\triangle \mathrm{E} 9$ hPS1 and cKO PS1 animals show expression changes in the same direction, this would suggest that these changes are related to the "loss of function" effect of the human mutant PS1. When compared with the wt $h P S 1$ transgenic animal (also referred to as a "TG comparison"), $\Delta$ E9 hPS1 mice reported 71 gene expression changes (supplemental material 4, available at www.jneurosci.org). The expression ratios of these 71 genes identified as differentially expressed were highly correlated between the HC and FC comparisons $(r=0.97 ; p<0.0001)$. Twenty-two genes were downregulated, whereas 49 genes were upregulated in these animals. Contrary to the cKO comparison, the $\triangle \mathrm{E} 9$ hPS1 mice showed more robust transcript upregulations than mRNA level reductions. Selected expression changes were verified for several genes on two additional pairs of transgenic animals using in situ hybridization (Fig. 2). In these experiments, maternally expressed gene 3 (MEG3), exostoses-like 2 (EXL2), hippocampus-abundant transcript 1 (HIAT1), activity-related cytoskeletal protein (ARC), and amylase 1A (AMY1A) all validated the microarray-predicted expression changes between the two sets of transgenic animals.

When the two datasets were cross-compared, 30 genes showed a robust and significant change in both TG and cKO comparisons. When the normalized adjusted intensities for the whole dataset were two-way clustered for the commonly changed 30 genes, the four experimental groups (wt mPS1, hPS1, $\Delta \mathrm{E} 9 \mathrm{hPS1}$, and $\mathrm{cKO}$ mPS1) separated into distinct clusters (Fig. 1, bottom). The $\triangle \mathrm{E} 9$ hPS1 and the cKO mPS1 mice showed the greatest Euclidian distance, with the two control groups ( $h P S 1$ and mPS1) clustering in between. For the group of 30 genes, there was a high correlation in the expression ratio between the $\mathrm{HC}$ and $\mathrm{FC}$ across the two conditions and within the $\Delta \mathrm{E} 9$ and $\mathrm{cKO}$ mice (Fig. 3 ). FDR assessment by permutation of the dataset suggested that by random chance, less than one gene would show the observed gene expression changes ( $<2 \%$ of the observed changes) (supplemental material 1, available at www.jneurosci.org)

Of the 30 genes, 23 genes were regulated in the opposite direction (up-down or down-up), whereas seven showed expression changes that were similar in direction (Table 1). For all genes, HC and FC data reported a consistent change of direction. Of the 23 transcripts that were regulated in an opposite direction in the TG and $\mathrm{cKO}$ mice comparisons, 11 genes reported increases in the $\triangle \mathrm{E} 9 \mathrm{hPS} 1$ mice and decreases in the cKO mPS1 mice, and 12 genes reported a decrease in the $\triangle \mathrm{E} 9 \mathrm{hPS} 1$ mice and increases in the $\mathrm{KO}$ mPS1 mice. Of the seven genes that were changed in the

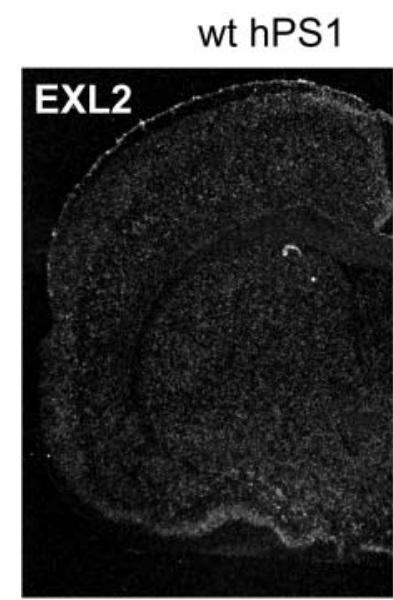

\section{delE9 hPs1}
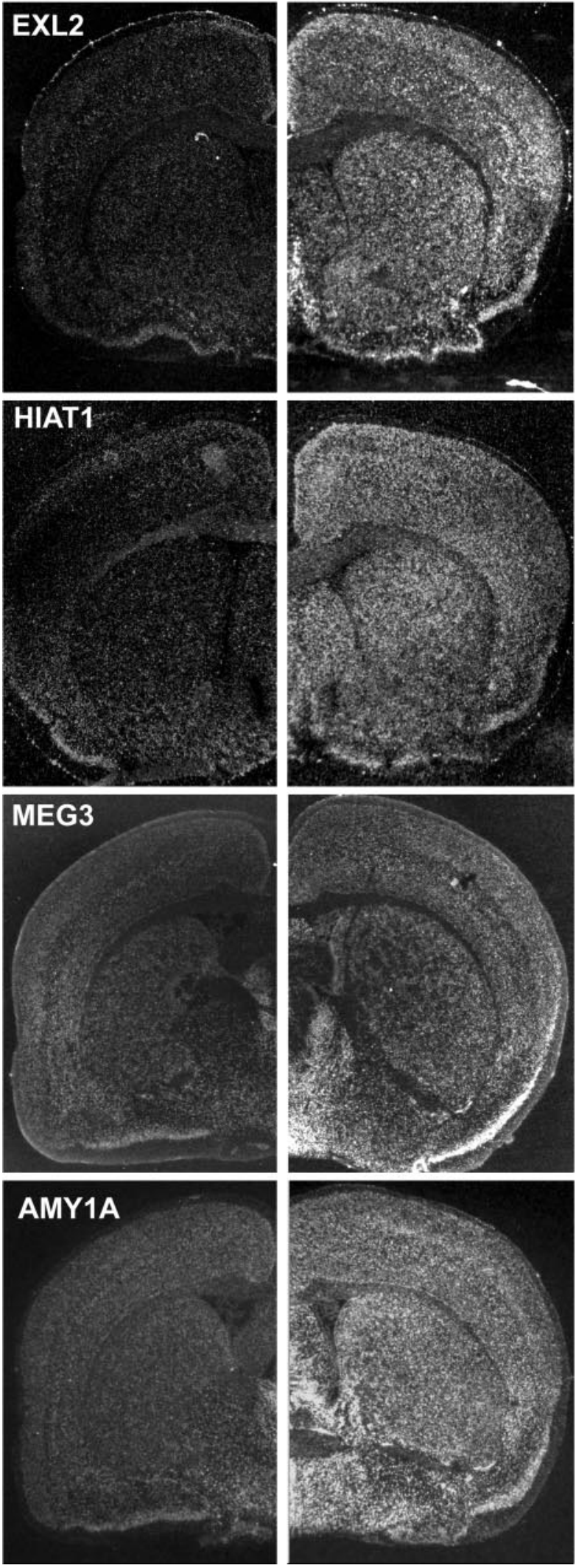

Figure 2. Verification of TG comparison data by in situ hybridization. Low-magnification, dark-field composite micrographs of $\triangle E 9$ hPS1 (right column) and wt $h$ PS1 (left column) mice brain sections. Riboprobes for EXL2, HIAT1, MEG3, and AMY1A were hybridized to 20- $\mu$ m-thick coronal sections using methods described previously. For the investigated genes, the in situ hybridization data were in concordance with the microarray findings. 
A.

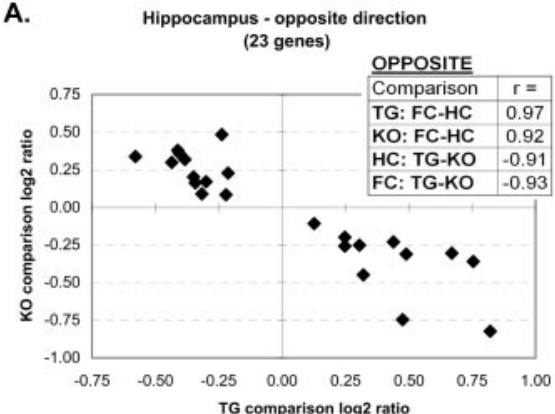

C.

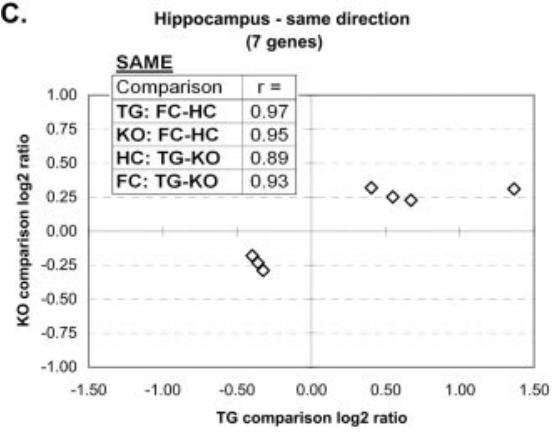

B.
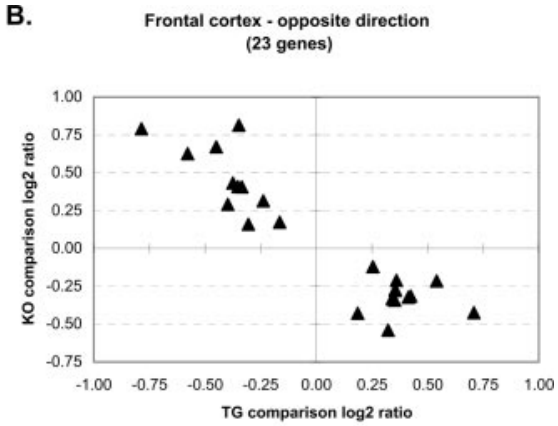

D.
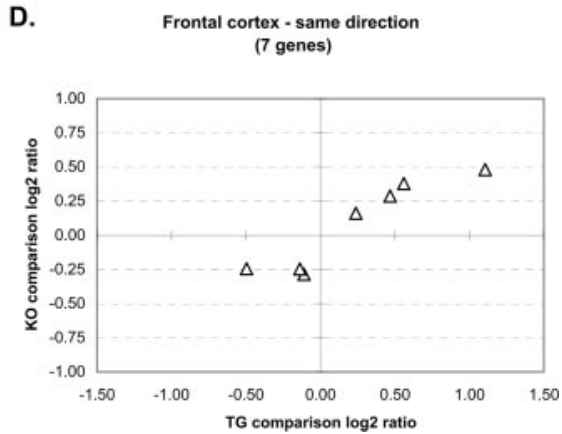

Figure 3. Coregulation of genes across the TG and cKO comparisons. $A, B$, Expression changes in the hippocampus $(A)$ and frontal cortex $(B)$ for the 23 genes changed in the opposite direction. The $x$-axis represents $T G$ comparison $\log _{2}$ ratio, and the $y$-axis denotes $C K O$ comparison $\log _{2}$ ratio. $C, D$, Expression changes of seven genes that were regulated in a similar direction in both the TG and cKO comparisons. Graph layout is similar to that in $A$ and $B$. Inserted tables in $A$ and $($ denote statistical correlations across the $\mathrm{TG}$ and $\mathrm{CKO}$ comparisons and across the two brain regions ( $\mathrm{HC}$ and FC). Note the high degree of transcript coregulation across both the TG and cKO comparisons and HC and FC.

same direction in both the $\Delta \mathrm{E} 9$ and cKO mice, four genes reported transcript induction and three genes reported transcript repression. In addition to the 30 genes that showed unequivocal regulation in both systems, we identified an additional 72 genes that showed some evidence for regulation in both the $\Delta \mathrm{E} 9$ and cKO comparisons (supplemental material 5, available at www. jneurosci.org). Although these gene probes satisfied only three of four statistical criteria we used in the current study [average $\log _{2}$ ratio (ALR) $>0.20$ and $p<0.05$ in both TG and cKO comparisons], this group very likely contains biologically meaningful data, because of the following: (1) the majority of the probes in this group still reported an overall significance across the combined dataset; (2) eight genes were represented with multiple, independent probe sets that showed consistent findings; (3) 63 of the 72 probes showed consistent results between the $\mathrm{HC}$ and FC comparison; (4) two-way clustering of the 102 putatively changed genes resulted in an outstanding separation of the $\Delta \mathrm{E} 9$ $h P S 1$ and $\mathrm{KKO}$ mPS1 experimental groups (supplemental material 6, available at www.jneurosci.org); and (5) FDR assessment suggested that $\sim 80 \%$ of the observed gene expression changes can be attributed to real data discovery (supplemental material 1, available at www.jneurosci.org).

Although the expression of $\triangle \mathrm{E} 9$ hPS1 leads to elevated $\mathrm{A} \beta_{42}$ production, the overall level of $A \beta$ production is extremely low in the brains of nontransgenic mice. As a result, we felt it was critical to investigate $\triangle \mathrm{E} 9 \mathrm{hPS} 1$-driven expression changes in the context of high-APP levels. To achieve this, we compared the expression in the hippocampus of five $\triangle \mathrm{E} 9 \mathrm{hPS} 1$ mutant mice to that of eight $\triangle \mathrm{E} 9 h P S 1 \times \mathrm{APP}_{695}$ Swe mice generated in our previous study (Lazarov et al., 2002). Surprisingly, the commonly regulated 30 genes that were the most strongly regulated in both the TG and
cKO comparisons (Table 1) showed a strong inverse correlation $(r=-0.72 ; p<$ $0.001)$ in the $\triangle \mathrm{E} 9 h P S 1 \times \mathrm{APP}_{695}$ Swe versus $\triangle \mathrm{E} 9$ hPS1 comparison: 25 of the 30 genes examined showed an expression change that was opposite in direction than observed in the $\triangle \mathrm{E} 9 \mathrm{hPS} 1$ versus wt $h P S 1$ comparison (Fig. 4).

Finally, for seven of the 30 genes across the five different groups of mice (wt hPS1, $\triangle \mathrm{E} 9 \mathrm{hPS} 1$, wt $m P S 1$, cKO $m P S 1$, and $\triangle \mathrm{E} 9$ $h P S 1 \times \mathrm{APP}_{695}$ Swe), we decided to confirm the expression changes by real-time qPCR in the hippocampus (Fig. 5). In the qPCR assessment, Fos, DUSP1 (MAP kinase phosphatase-1, serine/threoninespecific protein phosphatase), ARC, EXL2, cyclin D1, C1Qb, and C1Qg expression levels were changed in the microarray-predicted direction. The microarray-reported expression changes (ALR) were highly correlated $(r=0.91 ; p<$ 0.001 ), with the qPCR reported expression changes $(\Delta \Delta \mathrm{Ct})$ across the five different sample groups. The expression changes were more robust in the qPCR data than the GeneChip findings, suggesting that the microarray dataset may underestimate the actual expression differences.

\section{Discussion}

In this study, we identified the transcriptome profile of $\triangle \mathrm{E} 9$ hPS1, wt $h P S 1$, cKO $m P S 1$, and wt $m P S 1$ mice. Transcriptome responses observed in both the TG and cKO comparisons were highly correlated between the HC and FC. Thirty genes that were changed in the $\triangle \mathrm{E} 9 \mathrm{hPS} 1-\mathrm{wt}$ hPS1 comparison also showed an expression change in the mPS1ablated and wild-type mice comparison, suggesting that these expression changes represent the critical effect of the $\triangle \mathrm{E} 9$ hPS1 variant on the transcriptome. In the second part of this study, the comparison of $\triangle \mathrm{E} 9 \mathrm{hPS} 1$ with the $\triangle \mathrm{E} 9 \mathrm{hPS} 1 \times \mathrm{APP}_{695}$ Swe mice revealed that the combined expression of $\triangle \mathrm{E} 9 \mathrm{hPS} 1$ and $\mathrm{APP}_{695}$ Swe has a very strong influence on the expression of the same 30 genes identified in the TG and cKO comparisons: 25 of the 30 genes reported transcript level changes that were opposite in direction to those observed in the $\triangle \mathrm{E} 9 \mathrm{hPS} 1$ single mutants.

\section{The effect of PS1 mutation on the transcriptome: gain of function or loss of function?}

FAD-linked PS1 variants have been primarily considered to lead to a gain of function. However, recent data suggest that these FAD-linked PS1 variants, in addition to gain of function effects, may also lead to loss of function properties (Cai et al., 2003; De Strooper and Woodgett, 2003; Marjaux et al., 2004; Saura et al., 2004). Our dataset is very informative in this regard: 23 of 30 genes (and 72 of 102 genes in the extended dataset) showed expression alterations that were opposite in direction between the TG and cKO comparisons. These data strongly support the view that, at least at the transcriptome level, the expression changes associated with the $\triangle \mathrm{E} 9 \mathrm{hPS} 1$ mutation are a result of a gain of function. However, it should be noted that the $\triangle \mathrm{E} 9$ hPS1 expression did not result only in transcript increases. Rather, expression increases and decreases were evenly distributed (11 upregulations 
and 12 downregulations), suggesting that transcript downregulations may be an equally important consequence of the $\Delta \mathrm{E} 9$ hPS1 mutation as the upregulations; the obtained data argues that the mutant $\triangle \mathrm{E} 9$ $h P S 1$ is also a potent negative regulator of transcript levels.

The minority of genes (seven transcripts) were regulated in the same direction in the TG and cKO comparisons. The finding that the $\triangle \mathrm{E} 9 \mathrm{hPS} 1$ mutation produces some of the same effects as seen in PS1 ablation is not unexpected and represents a strong argument for loss of function events that may occur in conjunction with this mutation.

\section{The critical PS1-dependent transcript network}

The expression levels of 30 genes that we identified in both the TG and cKO comparisons strongly depend on PS1 expression and function. Multiple genes of this group have been previously associated with $\mathrm{AD}$, neurodegenerative diseases, or cognitive performance. Increased immunoreactivity for Fos-related proteins in Alzheimer's disease has been observed in multiple studies (Zhang et al., 1992; Anderson et al., 1994; Marcus et al., 1998), and activation of c-Fos contributes to amyloid $\beta$-peptide-induced neurotoxicity (Gillardon et al., 1996). In addition to Fos and Arc, several other genes we found have been implicated in the pathophysiology of $\mathrm{AD}$ and/or cognitive processes. For example, strong upregulation of Gadd45, indicating DNA damage, is an early event in A $\beta$ cytotoxicity (Santiard-Baron et al., 1999). Furthermore, the presence of neuronal nitric oxide synthase (NOS) in pyramidal-like neurons is a distinct characteristic of AD (Fernandez-Vizarra et al., 2004), and familial PS1 mutations in the N-terminal fragment cause NOS inhibitor-sensitive neuronal cell death (Hashimoto et al., 2004). In addition, C1q has been postulated to play a significant role in $\mathrm{AD}$ pathogenesis by multiple studies (Matsuoka et al., 2001; Luo et al., 2003; Veerhuis et al., 2003; Fonseca et al., 2004). In a transgenic animal model, Matsuoka et al. (2001) found that C1q levels increase as a result of fibrillar $A \beta$ production, whereas Veerhuis et al. (2003) argue that C1qcontaining $\mathrm{A} \beta$ deposits precede, or occur commensurate with, neurodegenerative changes in AD. Furthermore, Luo et al. (2003) suggest that the $\mathrm{C} 1 \mathrm{q}$ may mediate neuronal injury during $\mathrm{AD}$ by contributing to neuronal oxidative stress and neuronal demise. Finally, it is known that Tau protein and, in some cases, neurofilament subunits exhibit abnormal phosphorylation on specific serine and threonine residues in $\mathrm{AD}$ and frontotemporal dementia (for re$\Delta$ E9 hPS1 comparisons.

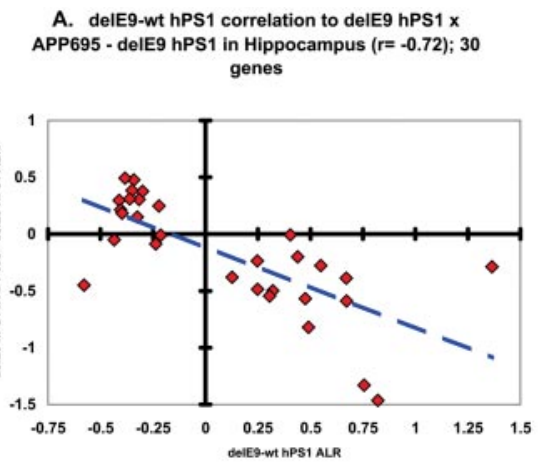

B. 11 genes increased TG -decreased KO

\section{C. $\mathbf{1 2}$ genes decreased TG - increased KO}
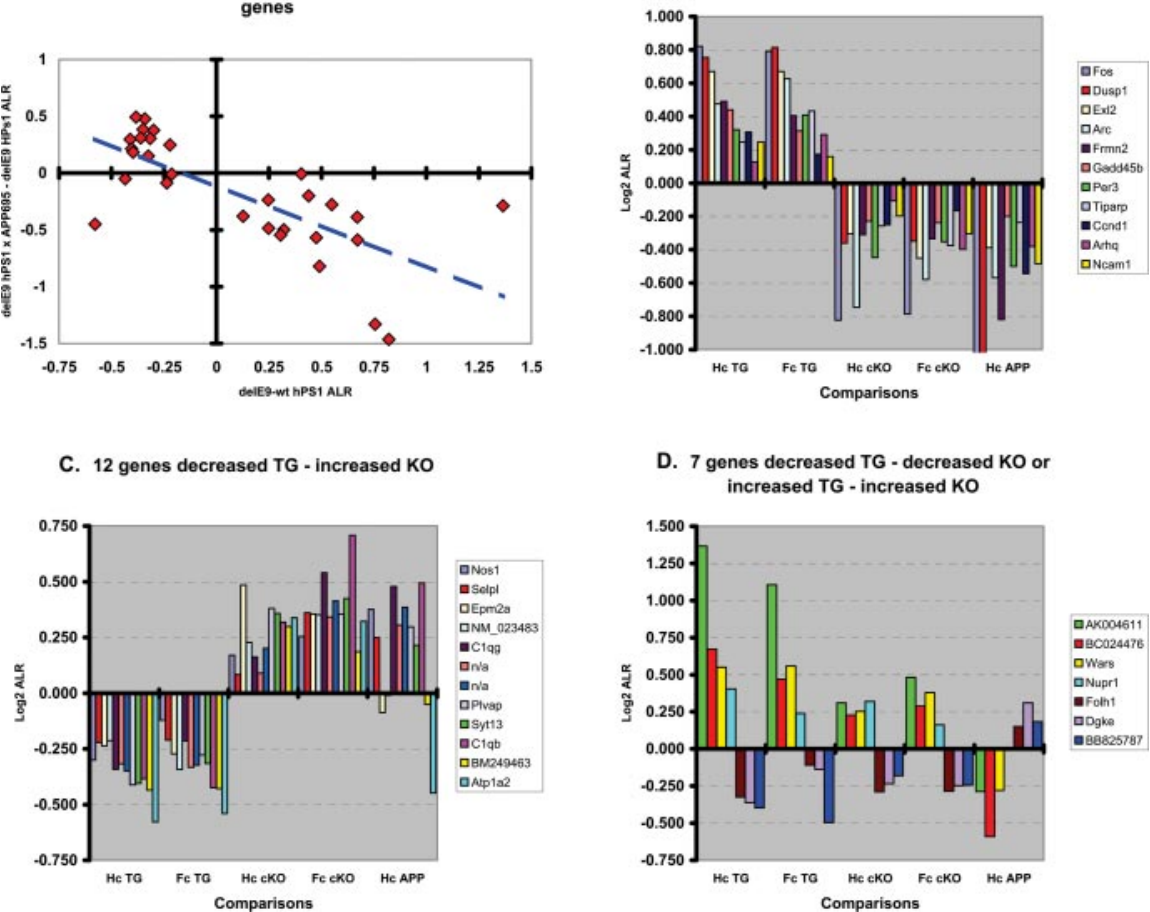

Figure 4. Coregulation of gene expression between the $\triangle \mathrm{E} 9$ hPS1 $\times \mathrm{APP}_{695}$ double-transgenic and $\Delta \mathrm{E} 9 \mathrm{hPS1}$ singletransgenic animals. $A$, The 30 genes identified in the TG and cK0 comparisons also showed robust transcription changes in the $\Delta \mathrm{E} 9$ $h P S 1 \times A_{\text {PPP }}$ mice. The $x$-axis represents TG comparison $\log _{2}$ ratio $(\Delta \mathrm{E} 9 h P S 1$ vs wt $h P S 1)$, and the $y$-axis denotes $\Delta \mathrm{E} h P S 1 \times$ $\mathrm{APP}_{695}$ versus $\triangle \mathrm{E} 9 \mathrm{hPS1}$ comparison $\log _{2}$ ratio in the hippocampus. The blue dashed line represents the trend line. Note that the 30 genes examined show a strong and inverse coregulation ( $r=-0.72 ; p<0.001)$ across the two comparisons, suggesting a robust effect of APP on the $\Delta \mathrm{E} 9 h P S 1$ background. $B-D$, Individual gene expression changes across the $\Delta \mathrm{E} h P S 1 \times \mathrm{APP}_{695}$ versus $\triangle \mathrm{E} 9 \mathrm{hPS1}$ comparison. The $x$-axis represents sample class, and the $y$-axis denotes comparison $\log _{2}$ ratio. For gene abbreviations, see Table 1. Note that the majority of genes are regulated in different directions between the TG and $\Delta \mathrm{E} 9 \mathrm{hPS} 1 \times \mathrm{APP}_{695}$ versus
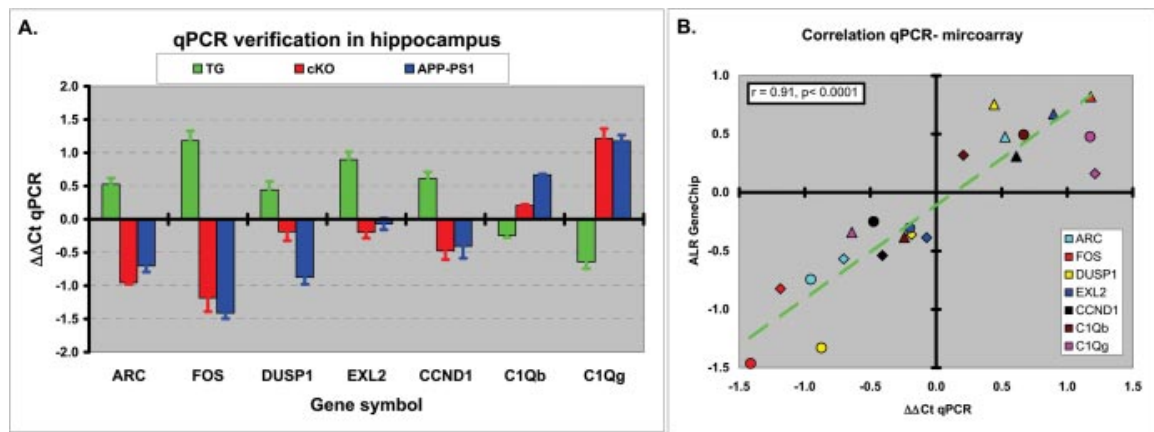

Figure 5. RT-qPCR verification of microarray data for seven genes. $A$, The $x$-axis represents genes, and the $y$-axis denotes average $\Delta \Delta$ Ct from two independent reverse transcriptions ( 4 replicates each). The green bars denote TG comparison ( $\Delta$ E9 $h P S 1$ vs wt $h P S 1$ ), the red bars correspond to CKO comparison (CKO mPS1 vs wt MPS1), and the blue bars indicate expression change in the APP-PS1 comparison $\left(\triangle \mathrm{E} \mathrm{hPS} 1 \times \mathrm{APP}_{695}\right.$ vs $\triangle \mathrm{E} 9 \mathrm{hPS1}$ ). Error bars denote SD. For gene symbols, see Table 1. $B$, Correlation of microarray data with $\mathrm{qPCR}$ data. The $x$-axis represents $\mathrm{qPCR} \Delta \Delta \mathrm{Ct}$, and the $y$-axis denotes the ALR established in the microarray comparisons. Colors denote different genes, and shapes denote comparisons (triangle, TG comparison; circle, cKO comparison; diamond, APP_PS1 comparison). The green dashed line denotes the linear trend. Note that the data show a strong and significant correlation $(r=0.91 ; p<0.0001)$.

view, see Morfini et al., 2002), and this may be directly related to the expression changes in DUSP1 we observed.

Recent studies of Dickey et al. $(2003,2004)$ are highly relevant for the interpretation of our dataset. Although these studies and our present dataset were generated with very different experimental parameters (age of mice, pooling, replicates, strain of 
mice, controls, and microarray platform used), they both report a downregulation of several genes (e.g., Arc, Egr, Fos) in the APP $\times$ PS1 double-mutant mice. Thus, the combined data suggest that the expression changes in at least some of the genes we observed is a persistent hallmark of the disease model. These changes appear to be present both before the pathology develops ( 3 months; our present dataset) and during the $A \beta$ deposition phase (17-18 months) (Dickey et al., 2003). Furthermore, this downregulation is observed in two different lines of mutant mice $\left[\mathrm{APP}_{\mathrm{K} 670 \mathrm{~N}, \mathrm{M} 671 \mathrm{~L}} \times P S 1-5.1\right.$ (Dickey et al., 2003) and $\mathrm{APP}_{695}$ Swe $\times \Delta \mathrm{E} 9$ PS1 (our study)] and suggests that this process is directly related to the pathophysiological processes associated with the expression of mutant APP and PS1 variants, rather than the exact experimental model.

\section{Directionality of expression changes}

Regulation of the 30 genes across the different conditions also argues that these are part of a common, strongly coregulated, transcript network that depends on normal PS1 function. These genes indicate an intriguing expression pattern across the hippocampus of the TG, conditional $\mathrm{KO}$, and $\Delta \mathrm{E} 9 h P S 1 \times \mathrm{APP}_{695}$ Swe versus $\triangle \mathrm{E} 9 \mathrm{hPS} 1$ comparisons, suggesting that they may be critically involved in pathophysiological changes that lead to experimental AD and perhaps human pathology. In this context, we interpret that the majority of expression changes in the TG comparison are the result of gain of function effects of the $\Delta \mathrm{E} 9 \mathrm{hPS} 1$. However, because the level of endogenously generated $A \beta_{42}$ in mouse brain is extremely low (Duff et al., 1996), the small increase in the levels of $\mathrm{A} \beta_{42}$ after expression of mutant PS1 may be stimulatory rather than toxic. Nevertheless, it is important to point out that in our system, the mutant PS1-dependent expression changes clearly depend on APP/A $\beta$ levels. Once the same mutant PS1 is coexpressed with APP (in the $\triangle \mathrm{E} 9 h P S 1 \times \mathrm{APP}_{695}$ Swe mice), the levels of APP, as well as the neurotoxic $\mathrm{A} \beta_{42}$ peptide, are markedly elevated, leading to expression changes that are opposite those observed in the $\triangle \mathrm{E} 9$ hPS1 single-mutant mice. Based on our results, we argue that the physiological effects of expressing PS1 mutants have two essential components: one that is constant and is a direct result of the mutation, and a second that depends on APP and $\mathrm{A} \beta_{42}$ levels.

At present, the role of those genes that are subject to PS1dependant regulation are not established, but we suggest that for at least a subset of these genes, the levels of expression may be critical for cognitive performance. For example, disruption of Arc, Fos, or Egr-1 expression, either by intrahippocampal administration of antisense oligonucleotides or by germline disruption,

impairs consolidation of long-term memory formation (Guzowski, 2002; Steward and Worley, 2002; Vazdarjanova et al., 2002; Montag-Sallaz and Montag, 2003). Furthermore, elegant microarray studies on aging by Blalock et al. (2004) have also identified Arc and NR4A as important aging- and cognitionrelated genes. Thus, we speculate that the observed gene expression changes may be directly relevant for the pathophysiology of aging, cognition, and/or Alzheimer's disease.

\section{References}

Anderson AJ, Cummings BJ, Cotman CW (1994) Increased immunoreactivity for Jun- and Fos-related proteins in Alzheimer's disease: association with pathology. Exp Neurol 125:286-295.

Ball CA, Sherlock G, Parkinson H, Rocca-Sera P, Brooksbank C, Causton HC, Cavalieri D, Gaasterland T, Hingamp P, Holstege F, Ringwald M, Spellman P, Stoeckert Jr CJ, Stewart JE, Taylor R, Brazma A, Quackenbush J (2002) Standards for microarray data. Science 298:539.

Blalock EM, Geddes JW, Chen KC, Porter NM, Markesbery WR, Landfield PW (2004) Incipient Alzheimer's disease: microarray correlation analy- ses reveal major transcriptional and tumor suppressor responses. Proc Natl Acad Sci USA 101:2173-2178.

Borchelt DR, Thinakaran G, Eckman CB, Lee MK, Davenport F, Ratovitsky T, Prada CM, Kim G, Seekins S, Yager D, Slunt HH, Wang R, Seeger M, Levey AI, Gandy SE, Copeland NG, Jenkins NA, Price DL, Younkin SG, Sisodia SS (1996) Familial Alzheimer's disease-linked presenilin 1 variants elevate Abeta1-42/1-40 ratio in vitro and in vivo. Neuron 17:1005-1013.

Borchelt DR, Ratovitski T, van Lare J, Lee MK, Gonzales V, Jenkins NA, Copeland NG, Price DL, Sisodia SS (1997) Accelerated amyloid deposition in the brains of transgenic mice coexpressing mutant presenilin 1 and amyloid precursor proteins. Neuron 19:939-945.

Brazma A, Hingamp P, Quackenbush J, Sherlock G, Spellman P, Stoeckert C, Aach J, Ansorge W, Ball CA, Causton HC, Gaasterland T, Glenisson P, Holstege FC, Kim IF, Markowitz V, Matese JC, Parkinson H, Robinson A, Sarkans U, Schulze-Kremer S, et al. (2001) Minimum information about a microarray experiment (MIAME)-toward standards for microarray data. Nat Genet 29:365-371.

Cai D, Leem JY, Greenfield JP, Wang P, Kim BS, Wang R, Lopes KO, Kim SH, Zheng H, Greengard P, Sisodia SS, Thinakaran G, Xu H (2003) Presenilin-1 regulates intracellular trafficking and cell surface delivery of beta-amyloid precursor protein. J Biol Chem 278:3446-3454.

Causton HC, Game L (2003) MGED comes of age. Genome Biol 4:351.

Colangelo V, Schurr J, Ball MJ, Pelaez RP, Bazan NG, Lukiw WJ (2002) Gene expression profiling of 12633 genes in Alzheimer hippocampal CA1: transcription and neurotrophic factor down-regulation and upregulation of apoptotic and pro-inflammatory signaling. J Neurosci Res $70: 462-473$.

De Strooper B (2003) Aph-1, Pen-2, and nicastrin with presenilin generate an active gamma-secretase complex. Neuron 38:9-12.

De Strooper B, Woodgett J (2003) Alzheimer's disease: mental plaque removal. Nature 423:392-393.

Dickey CA, Loring JF, Montgomery J, Gordon MN, Eastman PS, Morgan D (2003) Selectively reduced expression of synaptic plasticity-related genes in amyloid precursor protein + presenilin-1 transgenic mice. J Neurosci 23:5219-5226.

Dickey CA, Gordon MN, Mason JE, Wilson NJ, Diamond DM, Guzowski JF, Morgan D (2004) Amyloid suppresses induction of genes critical for memory consolidation in APP + PS1 transgenic mice. J Neurochem $88: 434-442$.

Duff K, Eckman C, Zehr C, Yu X, Prada CM, Perez-tur J, Hutton M, Buee L, Harigaya Y, Yager D, Morgan D, Gordon MN, Holcomb L, Refolo L, Zenk B, Hardy J, Younkin S (1996) Increased amyloid-beta42(43) in brains of mice expressing mutant presenilin 1. Nature 383:710-713.

Edgar R, Domrachev M, Lash AE (2002) Gene expression omnibus: NCBI gene expression and hybridization array data repository. Nucleic Acids Res 30:207-210.

Feng R, Rampon C, Tang YP, Shrom D, Jin J, Kyin M, Sopher B, Miller MW, Ware CB, Martin GM, Kim SH, Langdon RB, Sisodia SS, Tsien JZ (2001) Deficient neurogenesis in forebrain-specific presenilin-1 knockout mice is associated with reduced clearance of hippocampal memory traces. Neuron 32:911-926.

Fernandez-Vizarra P, Fernandez AP, Castro-Blanco S, Encinas JM, Serrano J, Bentura ML, Munoz P, Martinez-Murillo R, Rodrigo J (2004) Expression of nitric oxide system in clinically evaluated cases of Alzheimer's disease. Neurobiol Dis 15:287-305.

Fonseca MI, Kawas CH, Troncoso JC, Tenner AJ (2004) Neuronal localization of C1q in preclinical Alzheimer's disease. Neurobiol Dis 15:40-46.

Gan L, Ye S, Chu A, Anton K, Yi S, Vincent VA, von Schack D, Chin D, Murray J, Lohr S, Patthy L, Gonzalez-Zulueta M, Nikolich K, Urfer R (2004) Identification of cathepsin B as a mediator of neuronal death induced by $\mathrm{A} \beta$-activated microglial cells using a functional genomics approach. J Biol Chem 279:5565-5572.

Gillardon F, Skutella T, Uhlmann E, Holsboer F, Zimmermann M, Behl C (1996) Activation of c-Fos contributes to amyloid beta-peptide-induced neurotoxicity. Brain Res 706:169-172.

Ginsberg SD, Hemby SE, Lee VM, Eberwine JH, Trojanowski JQ (2000) Expression profile of transcripts in Alzheimer's disease tangle-bearing CA1 neurons. Ann Neurol 48:77-87.

Guzowski JF (2002) Insights into immediate-early gene function in hippocampal memory consolidation using antisense oligonucleotide and fluorescent imaging approaches. Hippocampus 12:86-104. 
Hashimoto Y, Tsukamoto E, Niikura T, Yamagishi Y, Ishizaka M, Aiso S, Takashima A, Nishimoto I (2004) Amino- and carboxyl-terminal mutants of presenilin 1 cause neuronal cell death through distinct toxic mechanisms: study of 27 different presenilin 1 mutants. J Neurosci Res 75:417-428.

Ho L, Guo Y, Spielman L, Petrescu O, Haroutunian V, Purohit D, Czernik A, Yemul S, Aisen PS, Mohs R, Pasinetti GM (2001) Altered expression of a-type but not b-type synapsin isoform in the brain of patients at high risk for Alzheimer's disease assessed by DNA microarray technique. Neurosci Lett 298:191-194.

Irizarry RA, Bolstad BM, Collin F, Cope LM, Hobbs B, Speed TP (2003a) Summaries of Affymetrix GeneChip probe level data. Nucleic Acids Res 31:e15.

Irizarry RA, Hobbs B, Collin F, Beazer-Barclay YD, Antonellis KJ, Scherf U, Speed TP (2003b) Exploration, normalization, and summaries of high density oligonucleotide array probe level data. Biostatistics 4:249-264.

Lazarov O, Lee M, Peterson DA, Sisodia SS (2002) Evidence that synaptically released $\beta$-amyloid accumulates as extracellular deposits in the hippocampus of transgenic mice. J Neurosci 22:9785-9793.

Lee MK, Borchelt DR, Kim G, Thinakaran G, Slunt HH, Ratovitski T, Martin LJ, Kittur A, Gandy S, Levey AI, Jenkins N, Copeland N, Price DL, Sisodia SS (1997) Hyperaccumulation of FAD-linked presenilin 1 variants in vivo. Nat Med 3:756-760.

Lepre J, Rice JJ, Tu Y, Stolovitzky G (2004) Genes@Work: an efficient algorithm for pattern discovery and multivariate feature selection in gene expression data. Bioinformatics 20:1033-1044.

Loring JF, Wen X, Lee JM, Seilhamer J, Somogyi R (2001) A gene expression profile of Alzheimer's disease. DNA Cell Biol 20:683-695.

Luo X, Weber GA, Zheng J, Gendelman HE, Ikezu T (2003) C1qcalreticulin induced oxidative neurotoxicity: relevance for the neuropathogenesis of Alzheimer's disease. J Neuroimmunol 135:62-71.

Marcotte ER, Srivastava LK, Quirion R (2003) cDNA microarray and proteomic approaches in the study of brain diseases: focus on schizophrenia and Alzheimer's disease. Pharmacol Ther 100:63-74.

Marcus DL, Strafaci JA, Miller DC, Masia S, Thomas CG, Rosman J, Hussain S, Freedman ML (1998) Quantitative neuronal c-fos and c-jun expression in Alzheimer's disease. Neurobiol Aging 19:393-400.

Marjaux E, Hartmann D, De Strooper B (2004) Presenilins in memory, Alzheimer's disease, and therapy. Neuron 42:189-192.

Matsuoka Y, Picciano M, Malester B, LaFrancois J, Zehr C, Daeschner JM, Olschowka JA, Fonseca MI, O’Banion MK, Tenner AJ, Lemere CA, Duff K (2001) Inflammatory responses to amyloidosis in a transgenic mouse model of Alzheimer's disease. Am J Pathol 158:1345-1354.

Mimmack ML, Brooking J, Bahn S (2004) Quantitative polymerase chain reaction: validation of microarray results from postmortem brain studies. Biol Psychiatry 55:337-345.

Mirnics K, Pevsner J (2004) Progress in the use of microarray technology to study the neurobiology of disease. Nat Neurosci 7:434-439.

Mirnics K, Middleton FA, Lewis DA, Levitt P (2001a) Analysis of complex brain disorders with gene expression microarrays: schizophrenia as a disease of the synapse. Trends Neurosci 24:479-486.

Mirnics K, Middleton FA, Stanwood GD, Lewis DA, Levitt P (2001b) Disease-specific changes in regulator of G-protein signaling 4 (RGS4) expression in schizophrenia. Mol Psychiatry 6:293-301.

Mirnics ZK, Mirnics K, Terrano D, Lewis DA, Sisodia SS, Schor NF (2003) DNA microarray profiling of developing PS1-deficient mouse brain reveals complex and coregulated expression changes. Mol Psychiatry 8:863-878.

Montag-Sallaz M, Montag D (2003) Learning-induced arg 3.1/arc mRNA expression in the mouse brain. Learn Mem 10:99-107.

Morfini G, Pigino G, Beffert U, Busciglio J, Brady ST (2002) Fast axonal transport misregulation and Alzheimer's disease. Neuromolecular Med 2:89-99.

Mufson EJ, Counts SE, Ginsberg SD (2002) Gene expression profiles of cholinergic nucleus basalis neurons in Alzheimer's disease. Neurochem Res 27:1035-1048.

Price DL, Tanzi RE, Borchelt DR, Sisodia SS (1998) Alzheimer's disease: genetic studies and transgenic models. Annu Rev Genet 32:461-493.
Rogaev EI, Sherrington R, Rogaeva EA, Levesque G, Ikeda M, Liang Y, Chi H, Lin C, Holman K, Tsuda T, Mar L, Sorbi S, Nacmias B, Piacentini S, Amaducci L, Chumakov I, Cohen D, Lannfelt L, Fraser PE, Rommens JM, et al. (1995) Familial Alzheimer's disease in kindreds with missense mutations in a gene on chromosome 1 related to the Alzheimer's disease type 3 gene. Nature 376:775-778.

Santiard-Baron D, Gosset P, Nicole A, Sinet PM, Christen Y, Ceballos-Picot I (1999) Identification of beta-amyloid-responsive genes by RNA differential display: early induction of a DNA damage-inducible gene, gadd 45 . Exp Neurol 158:206-213.

Saura CA, Choi SY, Beglopoulos V, Malkani S, Zhang D, Shankaranarayana Rao BS, Chattarji S, Kelleher III RJ, Kandel ER, Duff K, Kirkwood A, Shen J (2004) Loss of presenilin function causes impairments of memory and synaptic plasticity followed by age-dependent neurodegeneration. Neuron 42:23-36.

Scheuner D, Eckman C, Jensen M, Song X, Citron M, Suzuki N, Bird TD, Hardy J, Hutton M, Kukull W, Larson E, Levy-Lahad E, Viitanen M, Peskind E, Poorkaj P, Schellenberg G, Tanzi R, Wasco W, Lannfelt L, Selkoe D, et al. (1996) Secreted amyloid beta-protein similar to that in the senile plaques of Alzheimer's disease is increased in vivo by the presenilin 1 and 2 and APP mutations linked to familial Alzheimer's disease. Nat Med 2:864-870.

Selkoe DJ (2001) Presenilin, Notch, and the genesis and treatment of Alzheimer's disease. Proc Natl Acad Sci USA 98:11039-11041.

Sherrington R, Rogaev EI, Liang Y, Rogaeva EA, Levesque G, Ikeda M, Chi H, Lin C, Li G, Holman K, Tsuda T, Mar L, Foncin J-F, Bruni AC, Montesi MP, Sorbi S, Rainero I, Pinessi L, Nee L, Chumakov I, et al. (1995) Cloning of a gene bearing missense mutations in early-onset familial Alzheimer's disease. Nature 375:754-760.

Steward O, Worley P (2002) Local synthesis of proteins at synaptic sites on dendrites: role in synaptic plasticity and memory consolidation? Neurobiol Learn Mem 78:508-527.

Thinakaran G, Borchelt DR, Lee MK, Slunt HH, Spitzer L, Kim G, Ratovitsky T, Davenport F, Nordstedt C, Seeger M, Hardy J, Levey AI, Gandy SE, Jenkins NA, Copeland NG, Price DL, Sisodia SS (1996) Endoproteolysis of presenilin 1 and accumulation of processed derivatives in vivo. Neuron 17:181-190.

Van Gassen G, Annaert W (2003) Amyloid, presenilins, and Alzheimer's disease. Neuroscientist 9:117-126.

Vazdarjanova A, McNaughton BL, Barnes CA, Worley PF, Guzowski JF (2002) Experience-dependent coincident expression of the effector immediate-early genes arc and Homer $1 a$ in hippocampal and neocortical neuronal networks. J Neurosci 22:10067-10071.

Veerhuis R, Van Breemen MJ, Hoozemans JM, Morbin M, Ouladhadj J, Tagliavini F, Eikelenboom P (2003) Amyloid $\beta$ plaque-associated proteins $\mathrm{C} 1 \mathrm{q}$ and SAP enhance the $\mathrm{A} \beta 1-42$ peptide-induced cytokine secretion by adult human microglia in vitro. Acta Neuropathol (Berl) 105:135-144.

Wang CC, Kadota M, Nishigaki R, Kazuki Y, Shirayoshi Y, Rogers MS, Gojobori T, Ikeo K, Oshimura M (2004) Molecular hierarchy in neurons differentiated from mouse ES cells containing a single human chromosome 21. Biochem Biophys Res Commun 314:335-350.

Wheeler DL, Church DM, Edgar R, Federhen S, Helmberg W, Madden TL, Pontius JU, Schuler GD, Schriml LM, Sequeira E, Suzek TO, Tatusova TA, Wagner L (2004) Database resources of the National Center for Biotechnology Information: update. Nucleic Acids Res 32 [Database issue]:D35-D40.

Yao PJ, Zhu M, Pyun EI, Brooks AI, Therianos S, Meyers VE, Coleman PD (2003) Defects in expression of genes related to synaptic vesicle trafficking in frontal cortex of Alzheimer's disease. Neurobiol Dis 12:97-109.

Yu H, Saura CA, Choi SY, Sun LD, Yang X, Handler M, Kawarabayashi T, Younkin L, Fedeles B, Wilson MA, Younkin S, Kandel ER, Kirkwood A, Shen J (2001) APP processing and synaptic plasticity in presenilin-1 conditional knockout mice. Neuron 31:713-726.

Zhang P, Hirsch EC, Damier P, Duyckaerts C, Javoy-Agid F (1992) c-fos protein-like immunoreactivity: distribution in the human brain and over-expression in the hippocampus of patients with Alzheimer's disease. Neuroscience 46:9-21. 